\title{
EDITORIAL
}

\section{A ENFERMAGEM E O PROGRAMA DE INTERIORIZAÇÃO DO TRABALHO EM SAÚDE - PITS}

O Programa de Interiorização do Trabalho em Saúde em fase de implantação pelo Ministério da Saúde prevê a disponibilização de uma equipe mínima formada por enfermeiro e médico com responsabilidade de prestar cuidados integrais de saúde à população por um período de um ano. Esta programa pretende melhorar os indicadores de saúde de 150 municípios brasileiros, com menos de 50.000 habitantes que apresentam uma mortalidade infantil de 80 por mil nascidos vivos, prevalência de doenças como malária, hanseníase e tuberculose, localizados nas regiões norte, nordeste, centro-oeste e norte de Minas Gerais e que não estejam desenvolvendo o Programa Saúde da Família. Pretende com ele sensibilizar os governos locais para que a partir dai, dêem continuidade substituindo-o, gradativamente, pela estratégia saúde da família.

Em que pese os méritos do Programa consideramos que o impacto nos indicadores de saúde daquelas regiões será pouco visivel tendo em vista a sua amplitude e a maneira como está estruturado. Além disto perguntamos se o município terá um sistema organizado de referência e contra-referência capaz de responder com resolutividade os problemas de saúde que extrapolem à atenção básica; e se haverá, ainda, a continuidade do PITS, independente da sua absorção pelo governo local, uma vez que a comunidade exigirá este novo modelo de atenção à saúde.

Gostaríamos de discutir alguns aspectos da organização da equipe- enfermeira, médico e agentes comunitários de saúde. O Programa oferecerá à enfermeira e ao médico algumas vantagens como curso de especialização em atenção básica, uma oportunidade de experiência profissional enriquecedora e um salário acima da média de mercado. Entretanto, para viabilizar o Programa, ainda este ano, o governo estabelece uma precária relação de trabalho com os profissionais. Trata as enfermeiras de forma diferente ao definir, um valor menor para a bolsa destas profissionais, contrariando princípios do próprio governo federal que estabelece isonomia quando o sistema de bolsa salário é utilizado como forma de compensação financeira. A posição das organizações de enfermagem presentes na apresentação do programa pelo Ministério da Saúde foi enfática na defesa da isonomia de valores para a remuneração. No entanto prevaleceu a posição defendida pelas entidades médicas e encampadas pelo MS, deixando de considerar a histórica contribuição das enfermeiras na saúde pública do país, como podemos perceber, atualmente, ao participarem de forma vital na gestão do Programa Saúde da Família

O Programa que tem como meta se expandir para outros municípios brasileiros, para ter sucesso assegurado, terá que contar com a infra-estrutura que é de 
compromisso dos municípios, com a sua aceitação pela comunidade, tendo em vista a introdução de novas tecnologias e novas abordagens e, sobretudo, contar com o acompanhamento sistemático do processo de trabalho da equipe.

Joel Rolim Mancia

Editor 